dropped and elected officials prayed for rain. But even when the rains come, the problem is not fixed; and drought is sure to recur.

Fishman enjoys naming and shaming the villains. But he takes greater joy in celebrating the heroes: the laundries in Las Vegas, Nevada, and the citizens of Australia's Gold Coast who now recycle urban water. Fishman explores at length the paradox that whereas companies such as Coca-Cola - headquartered in Atlanta - and Campbell Soup, of Camden, New Jersey, have set themselves elaborate water strategies and water-saving measures, most cities, including Atlanta, have not.

He both praises and damns the private sector. The market can drive efficiency savings, he says, but it also creates solutions for problems that don't exist by, for example, "foisting bottled water on a too-gullible world", and fails to fix the real problems. He sees little future for a trade in water, because water cannot be transported easily over long distances. It's costly, politically and practically. Yet 'virtual' water - used in the production of coffee, T-shirts, cars and everything else we make - is traded with little heed for its economic or ecological value.

Technological advancement is and will be important, and Fishman covers it nicely. Given that the agricultural sector uses more than $70 \%$ of the global water supplies, surely everyone would be cheered by the idea of a high-yielding new crop variety that can mature using only $40 \%$ of the water? But if those crops are genetically engineered, more than one continent will recoil. Farmers who get water free or for little cost have no incentive to reduce their usage with water-saving devices. Nor are many of the new technologies taken up, even though someone invents a water purifier nearly every week that 'for only pennies per day will provide a family with clean drinking water.' The dispiriting truth is that few are bought.

The Big Thirst is a delight to read full of salient and fascinating examples, well-researched and laced with wry humour. It would be wonderful if Fishman's rant against bottled water converted every reader. It would be even better if it promoted a serious reflection on how little we value that on which our life depends.

\footnotetext{
Margaret Catley-Carlson serves on water and agricultural boards and advisory committees, including the World Economic Forum's Global Agenda Council on Water Security and the United Nations Secretary General Advisory Board on Water. e-mail:m.catley-carlson@cgiar.org
}

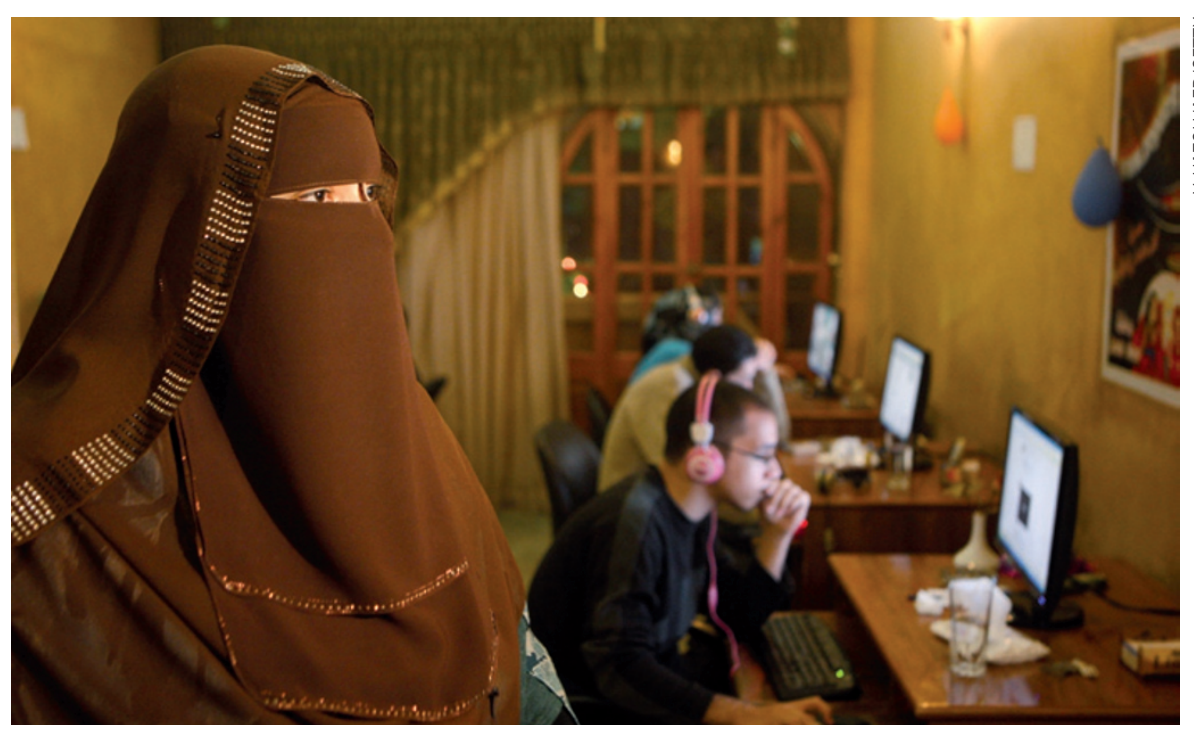

A blogger (left) for an Internet radio station in Egypt that fights intolerance towards divorced women.

TECHNOLOGY

\section{Together, bit by bit}

\section{A historian's insights into digital culture fascinate George Rousseau.}

$\mathrm{R}$ espected intellectual historian Milad Doueihi describes himself as an "accidental digitician" - by his own admission more a user of information technology than a creator of it. Such people, he argues in Digital Cultures, are forging a new global culture. The impact of computers on our minds, bodies and societies is already farreaching. Whether we like it or not, digital culture is permanently entrenched.

Doueihi, an expert on literacy, points out that the voices of historians have largely been missing from discussions of the Internet. By showing how modes of communication and human relationships have changed since its rise, he makes a persuasive case that digital culture has broken free from print culture, which extends from the Gutenberg Bible of the 1450 s to the present. Instant response, brevity, minimal spelling and grammar, novel syntax and different modes of composition have created new forms of literacy.

As a consequence, the way we view our identity, citizenship and political selfhood has changed. Doueihi sees blogging as "one of the greatest success stories". With the rise of online forums, everyone can communicate freely without publishers' intervention. As a result, we are more dedicated to the Internet than to any other civic cause, or even to our everyday work. As well as rich and poor, there is now another great social divide: between those with and without access to these web conversations.
In our online interactions, a new civility has emerged, along with the uncivilized behaviour - 'trollism' - that results from online anonymity. Urban dwellers blog more than those outside cities, and have created parallel cities in the blogosphere. And podcasts have reinvigorated the voice.

Doueihi's argument

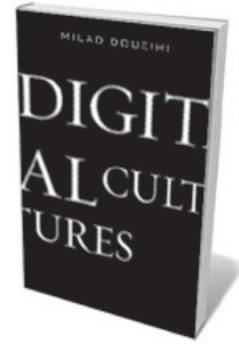

Digital Cultures MILAD DOUEIHI Harvard Univ. Press: $2011.175 p p$. $£ 14.95 / \$ 19.95$ for a culture shift rests on three components of the online world. One is its creation of an anthology. The digital culture, rather than creating long, sustained narratives, assembles fragments of material - but not into logical wholes. We invest everything in e-mail responses rather than saving up our thoughts for long letters or books. All these snippets can then be assembled by different readers in different ways.

Doueihi also briefly cites religion as a central aspect of any new culture, although he never explains what he means by the word 'religion'. He passes quickly on to the third component - group identity, arguing that we seem to have a greater craving for belonging than previous generations.

Digital group identity, says Doueihi, differs from previous print-based concepts in several 